Olga Caspers (Berlin)

\title{
«Кому, нафиг, сейчас нужна классика?!» (Об использовании мультимедийных материалов по литературе в РКИ)
}

Dieser Beitrag handelt vom Einsatz multimedialer Materialien, insbesondere aus dem Bereich der Literatur, im RaF (Russisch als Fremdsprache). Zuerst werden Modelle der Analyse von literarischen Werken aus der inter- und transkulturellen Perspektive dargestellt und an Beispielen zeitgenössischer AutorInnen (Linor Goralik, Oxxymiron und Slava Se) das Potenzial ihrer Anwendung im didaktischen Bereich gezeigt. Dann wird am Beispiel des Schaffens des bekannten russischen Rappers Oxxxymiron demonstriert, wie klassische Texte im RaF berïcksichtigt werden können. Außerdem wird hier ein Versuch unternommen, ein Korpus an multimedialen Texten von AutorInnen mit transkultureller Erfahrung zu erstellen, der unter anderem im Bereich des autonomen Lernens nach bereits eruierten Modellen eingesetzt werden kann.

The article presents multimedia texts as a rich and interesting literary material for teaching L2 Russian in German universities. In the beginning the author gives a review of the textbooks and studying materials that are used in Germany to teach the Russian language and literature. Then the author introduces a specific model of teaching literature from the intercultural and transcultural perspective. To illustrate the didactic model the author explains how it works using the lyrics of the popular Russian rapper Oxxxymiron. Besides, the author presents criteria for multimedia texts corpora that help choose the works of writers who have experienced inter- and transcultural communication.

В короткометражном фильме Анны Меликян Такое настроение, адажио Баха и небольшой фрагмент из жизни девушки Леньь вопрос

Anastasia Drackert und Katrin Bente Karl (Hg.), Didaktik der slawischen Sprachen

Beiträge zum 2. Arbeitskreis in Innsbruck (19.02.-20.02.2018)

(C) 2019 innsbruck university press, ISBN 978-3-903187-80-1, DOI 10.15203/3187-80-1 
значения классики в современной культуре возникает буквально с первых минут. Так, например, гастарбайтеры из Узбекистана, работающие на мусоровозе и уже достаточно давно являющиеся неотъемлемой частью московского быта, видят на улице пианино, стоящее у мусорного бака, и не утилизируют его в надежде на то, что оно еще кому-нибудь пригодится. Когда через неделю пианино все еще никто не забирает, один из рабочих выносит приговор современному состоянию культуры в столице: «Нафиг не нужна сейчас никому классика!», на что его коллега возражает: «Классика потому и классика, что всегда нужна!» (Меликян 2014, 12:01).

В фильме в целом и особенно в этой сцене заключаются основные тенденции и проблематика преподавания современной российской культуры в сфере РКИ, о которых пойдет речь ниже. Это прежде всего: 1) использование классики и/или обращение к массовой/повседневной культуре; 2) ориентация на приобретение набора компетенций в области меж- и транскультурной коммуникации ${ }^{1}$ (МиТКК) в условиях растущей миграции и глобализации, и непосредственно связанная с ней 3) необходимость работы с «транскультурными» материалами, а также 4) т.н. мультимедийность (комплексное задействование на занятиях не только печатных текстов, но и их цифровых разновидностей: современных видео- и аудиоматериалов).

Анна Меликян, на данный момент одна из самых популярных российских режиссеров, родилась в Баку, выросла в Армении, снимает фильмы в России, фиксируя в них, помимо прочего, состояние

${ }^{1}$ Подробнее о транскультурной коммуникации (принцип транскультурности): Билингвальное образование в немецкоязычных странах: модель транскультурного обучения (Касперс 2017), а также Брагина, Н.\& Касперс, О. (2018). При этом важно отметить, что меж- и транскультурный подход не исключают друг друга, а взаимодополняют, давая возможности изучения как национальных различий, так и сходств, являясь т.о. более эффективным методом в преподавании языка и культуры. Подробнее: Dawidowski, Christian et al. (2015)

Anastasia Drackert und Katrin Bente Karl (Hg.), Didaktik der slawischen Sprachen

Beiträge zum 2. Arbeitskreis in Innsbruck (19.02.-20.02.2018)

(C) 2019 innsbruck university press, ISBN 978-3-903187-80-1, DOI 10.15203/3187-80-1 
современной российской культуры глазами иностранки. Этот взгляд извне, обыгрывание культурных особенностей, а также выбор тематики и формы (киноновеллы, составляющие на уровне кинотекстов небольшие и удобные для работы пространства) делает ее фильмы интересными как в области методики преподавания, так и в культурологическом, меж- и транскультурном аспекте.

В данной статье речь пойдет об использовании культурологических мультимедийных материалов в рамках РКИ в немецких ВУЗах на основе интернет-порталов, видеоклипов, блогов, фильмов и т.д. Вначале дается обзор учебных материалов, используемых в Германии на занятиях по РКИ, с акцентом на то, как в них задействована художественная литература, после чего будут кратко представлены основные составляющие модели ее преподавания в аспекте меж- и транскультурной коммуникации, а в заключение продемонстрированы возможности работы с мультимедийными текстами на примере творчества «главного российского рэпера» Oxxxymirona (Нилов 2017).

Политика в области высшего образования в Германии за прошлое десятилетие, направленная, с одной стороны, на структуризацию бакалавриата и магистратуры, с другой стороны, на стандартизацию преподавания иностранных языков, привела к сокращению часов преподавания и тем самым увеличило значение т.н. автономного обучения. И поскольку акцент в преподавании иностранных языков делается традиционно на языковую сторону, это фактически привело к снижению роли литературы в процессе обучения. Использование литературы в рамках преподавания иностранных языков в Германии в этой связи стало ограничиваться задействованием ее меж- и транскультурного аспекта: т.е. для формирования навыков меж- и транскультурной коммуникации, а также - рефлексии прочитанного и усовершенствованию навыков аргументации и анализа (DeckeCornill \& Küster 2015: 237).

Anastasia Drackert und Katrin Bente Karl (Hg.), Didaktik der slawischen Sprachen

Beiträge zum 2. Arbeitskreis in Innsbruck (19.02.-20.02.2018)

(C) 2019 innsbruck university press, ISBN 978-3-903187-80-1, DOI 10.15203/3187-80-1 
Особый потенциал художественных произведений в области меж-/и транскультурной коммуникации, как например, существование нескольких «правильных» интерпретаций литературных произведений и наличие множества точек зрения различных персонажей, дающих возможность смены и координации перспективы, делает художественную литературу бесспорно важным материалом для преподавания РКИ в меж- и транскультурной перспективе именно в Германии. Прежде всего потому, что занятия по РКИ в немецких ВУЗах часто проходят в гетерогенных группах, студенты которых имеют разный миграционный «бэкграунд». Необходимо учитывать эту ситуацию при выборе текстов для работы и использовать практики, связанные с креолизацией культур, а также задействовать уже имеющиеся знания обучаемых в этой области, интенсивнее работая с современной литературой.

Особую группу изучающих русский язык в вузах Германии составляют т.н. «херитажники» (Brüggemann 2016: 39), носители русского языка как семейного/унаследованного (Polinsky 2010: 321), проблемы обучения которых не раз становились темами научных публикаций в последнее время. Для этой группы обучаемых использование творчества авторов, имеющих опыт меж- и транскультурной коммуникации, текстов с интерактивными возможностями (общение в соцсетях, комментирование, участие в разного рода культурных мероприятиях и наличие аудио- и видеоматериалов) представляет оптимальную основу для работы. Кроме того, для этой целевой аудитории важна другая тенденция литературной дидактики переход от пассивной рецепции литературы к написанию собственных текстов на основе обсуждаемых на занятии.

Традиционно в преподавании РКИ предпочтение отдается работе с русской классической литературой, представляющей традиции и обычаи прошлых веков. В условиях растущей миграции и глоба- 
лизации мирового сообщества применение классики в существующем формате лишь отчасти соответствует запросам обучаемых и в связи с этим требуется пересмотр материалов и методических принципов с учетом актуальных требований. Таким образом, меж- и транскультурные модели преподавания становятся особенно актуальными в условиях миграции и глобализации, а также связанных с этими процессами культурных изменений в немецком обществе. И поэтому, при выборе текстов для работы на занятиях по РКИ важно в принципе постепенно отказываться от понятий «русская» или «немецкая» национальная литературы, используя преимущественно т.н. транскультурную литературу в сфере РКИ. При выборе литературы необходимо в идеале учитывать возможность создания корпуса текстов, который может быть использован для автономного обучения. С одной стороны, он должен соответствовать интересам обучаемых, с другой - поддерживать баланс между преподаванием языка и литературы/культуры.

Кроме того, по нашему мнению, при использовании литературы в преподавании РКИ наряду с классикой необходимо переходить к задействованию более современных литературных форм, поскольку накопление символического культурного капитала (Bourdieu 1983) происходит не исключительно на основе классического литературного канона, а все больше за счет потребления продуктов массовой культуры - прежде всего, интернет-порталов и YouTube платформы. Современные интернет-порталы, а также каналы различных медийных персонажей на YouTube являются важной составляющей массовой культуры, формирующей ценностные установки и модели поведения нового поколения обучаемых. Выбор такого материала значительно повышает их мотивацию, создает благоприятную основу для меж- и транскультурного обучения и должен учитываться в создании новых учебных материалов и программ. Вместе с тем, в выборе литературных текстов важно обращать внимание на особен-

Anastasia Drackert und Katrin Bente Karl (Hg.), Didaktik der slawischen Sprachen

Beiträge zum 2. Arbeitskreis in Innsbruck (19.02.-20.02.2018)

(C) 2019 innsbruck university press, ISBN 978-3-903187-80-1, DOI 10.15203/3187-80-1 
ности восприятия нового поколения студентов-миллениалов. Поскольку ориентация на визуальность для этого поколения является более важной, чем, например, чтение текстов, то работа с текстами обязательно должна быть дополнена работой с визуальными материалами, больше соответствующими потребностям и привычкам миллениалов, чем традиционные (бумажные) учебные материалы.

\section{1. Вузовские учебники: традиция использования художественных произведений в преподавании РКИ}

Использование литературы в преподавании РКИ имеет долгую традицию. Современные учебные пособия, составленные российскими специалистами в области РКИ, такие как Поехали, Жили-были или 5 элементов активно используются в немецких вузах на занятиях и по-разному задействуют художественную литературу в учебных целях. Если у Эсмантовой в 5 элементах присутствуют исключительно функциональные тексты (Эсмантова 2009), адаптированные сказки типа Три медведя и тексты страноведческой направленности, то в Жили-были спектр предложенных литературных текстов достаточно широк (Миллер 2009). Наряду со страноведческими текстами в учебнике предлагается работать с адаптированными вариантами чеховских рассказов, стихотворениями Маяковского, повестями Куприна для внеклассного чтения, а также сатирическими текстами Довлатова и Аверченко. Кроме того, приводятся тексты таких авторов «женской прозы» как Маринина и Токарева в качестве внеклассного чтения, но без методических комментариев и заданий. Немецкие же учебные издательства своевременно отреагировали на изменение в сфере преподавания иностранных языков. Так, например, издательство Klett, выпустившее учебник Mocm 1 и 2 для современного преподавания русского языка, ориентируется на

Anastasia Drackert und Katrin Bente Karl (Hg.), Didaktik der slawischen Sprachen

Beiträge zum 2. Arbeitskreis in Innsbruck (19.02.-20.02.2018)

(C) 2019 innsbruck university press, ISBN 978-3-903187-80-1, DOI 10.15203/3187-80-1 
Общеевропейский Языковой Портфель (ОЕЯП). В первой части используются исключительно функциональные неаутентичные тексты, а также дается страноведческая информация на немецком языке. Зато уже вторая часть (уровень В1) содержит в первом уроке отрывок из романа Булгакова Мастер и Маргарита, с описанием встречи Берлиозом и Бездомным иностранца (как они думают, немца(!)) Воланда. И если в первом аутентичном тексте учебника задание сформулировано как «Расскажите, что вы узнали об иностранце» (Adler et al. c. 17), то в последней главе учебника уже дается отрывок из дневников Достоевского о его посещении Германии с заданиями, учитывающими требования креативного обращения с текстами, а также особенности межкультурной коммуникации. Авторы учебника выбрали для работы один из отзывов писателя о немцах, в качестве задания к которому обучаемым предлагается сделать дневниковую запись от имени русского классика о сегодняшней Германии (Adler et al. c. 87). В этом задании студентам предлагается не только возможность смены и координации перспективы (немецкий студент - российский классик), но и эксперимент с изменением жанра, исторической среды, а также возможность применения уже приобретенных знаний на занятиях по литературоведению и культурологии.

Другой учебник издательства Klett Ясно!, причисляющий себя к учебникам нового поколения, обходится без художественных текстов или даже упоминаний творчества классиков. Но для занятий на основе художественной литературы издательство рекомендует отдельную книгу для чтения на уровне В1 B поисках лучшей жизни с текстами, адаптированными, по данным авторов, на 75\% - 85\% (Genthner et al. 7). Для изучающих русский язык в университете, в том числе и для студентов - филологов, учебное пособие предлагает произведения трёх авторов (Пушкин Станционный смотритель, Улицкая Цю-юрих и Гришковец Шрам), соответствующие всем современным требованиям работы с литературными текстами на

Anastasia Drackert und Katrin Bente Karl (Hg.), Didaktik der slawischen Sprachen

Beiträge zum 2. Arbeitskreis in Innsbruck (19.02.-20.02.2018)

(C) 2019 innsbruck university press, ISBN 978-3-903187-80-1, DOI 10.15203/3187-80-1 
уроках иностранных языков. В нем предлагаются задания, направленные на приобретение или усовершенствование различных компетенций и навыков: выстраивание гипотез по отношению возможного/ожидаемого продолжения действий; логическое выстраивание сюжетного повествования на уровне формы и содержания; задания, предлагающие обучаемым работать со сменой/координацией перспективы; написание собственных текстов с учетом прочитанного; презентации и другие виды креативной работы по обсуждаемой тематике. В предисловии авторы указывают на то, что выбранные тексты знакомят читателей с различными историческими эпохами российской истории, представляют авторские концепты «счастья», предлагают материал для дискуссий, и кроме того, дают читателям возможность идентификации или выработки критического отношения к позиции персонажей на основе заданий в области МиТКК.

В учебнике Отлично! издательство Hueber не использует художественные тексты (A1-B1), но - как и Klett - прилагает к учебнику «экспериментальный» сборник легких текстов для чтения, в котором русская классика - Преступление и наказание, Анна Каренина и Мастер и Маргарита - пересказана на уровне A1 от лица главных персонажей. По аналогии можно давать задание студентам создать собственные тексты по мотивам других известных русских классиков или же изменить перспективу рассказчика в уже упомянутых. Этот вид заданий предлагает вести креативную работу с текстами, осмысленно использовать язык и предоставляет студентам отличную возможность уже на начальном этапе владения языком активно использовать приобретенные знания и навыки из области литературы и культурологии. Таким образом, обучаемый является не пассивным наблюдателем, а активно включается в процесс создания текста, наполняя его разными смыслами в соответствии со своими языковыми, культурными и другими компетенциями.

Anastasia Drackert und Katrin Bente Karl (Hg.), Didaktik der slawischen Sprachen

Beiträge zum 2. Arbeitskreis in Innsbruck (19.02.-20.02.2018)

(C) 2019 innsbruck university press, ISBN 978-3-903187-80-1, DOI 10.15203/3187-80-1 
Даже такой краткий обзор учебных материалов дает ясную картину того, как обстоят дела с использованием литературы в рамках РКИ: в российских учебниках идет установка на пассивное использование классической (реже массовой литературы - чаще всего так называемых «женских романов» Токаревой или Марининой) литературы: чтение для ознакомления, без заданий, направленных на активную работу с текстами. В немецких учебниках отразились инновации в сфере дидактики последних десятилетий и прежде всего влияние на них литературоведческих теорий (рецептивная эстетика) и теорий меж- и транскультурной коммуникации. В них предпочтение отдается более современным авторам, изображающим в своих произведениях повседневную жизнь, и заданиям, рассчитанным на креативную работу с текстом.

В последнее время в связи с многочисленными и значимыми переменами в сфере культуры и образования в Германии, о которых уже говорилось выше, возникла потребность пересмотреть методические основы использования литературы на занятиях по русскому языку, особенно для филологов-славистов. С одной стороны, изменились цели обучения в связи с переходом на т.н. «ориентированное на компетенции образование» (Bergmann 2016), а с другой, изменился контент обучаемых, с которыми преподаватели работают на занятиях.

Именно для этой целевой группы (херитажники, носители русского как семейного) необходимо использовать наряду с текстами классической и массовой литературы такие альтернативные жанры, как блоги и интернет-литература. А для поднятия «престижа» жанра лирики среди обучаемых рекомендуется работа с рэп-баттлами такого представителя этого направления, как Oxxxymiron. Тексты блогеров и т.н. баттлы (например, баттл Oxxхуmiron vs. Слава КПСС набрал на YouTube платформе больше десяти миллионов просмотров

Anastasia Drackert und Katrin Bente Karl (Hg.), Didaktik der slawischen Sprachen

Beiträge zum 2. Arbeitskreis in Innsbruck (19.02.-20.02.2018)

(C) 2019 innsbruck university press, ISBN 978-3-903187-80-1, DOI 10.15203/3187-80-1 
за один день) ${ }^{2}$ способны быстро реагировать на культурнообщественные изменения, которые происходят в России и на данный момент больше отвечают запросам нового поколения обучаемых, а также предлагают альтернативные форматы работы.

Для студентов-русистов необходимо разрабатывать такие материалы, которые, с одной стороны, соответствовали бы стандартам европейского преподавания, с другой стороны, отражали бы резонансные явления современной российской культуры. Особенно важно при этом, чтобы литературные тексты затрагивали вопросы филологии и создавались авторами, имеющими опыт в области межи транскультурной коммуникации. Именно поэтому в Берлинском университете имени Гумбольдта разрабатывается новая модель преподавания РКИ на основе литературы в аспекте МиТКК. Целью этой модели является более интенсивное включение в обучение текстов, прежде всего, современных авторов, активно присутствующих и практикующих общение в цифровых медийных сферах, обучение литературно-эстетическим навыкам и компетенциям, усовершенствование навыков в области меж- и транскультурной коммуникации, увеличение видов креативной работы с художественными текстами, задействование мультимедийных материалов на занятиях и при самостоятельном обучении.

Преподаватели романо-германских языков уже несколько лет используют меж- и транскультурный потенциал художественной литературы. Такие ученые-методисты как Кристиана Фэке и Грит Альтер разработали методологическую базу и модели работы с художественной литературой. Кристиана Фэке (Fäcke 2006) предлагает модель транскультурного обучения на основе литературных текстов, в центре повествования которых находятся практики, связанные с гибридизацией/креолизацией культур. Для преподавания

\footnotetext{
${ }^{2}$ Рэп-баттл между Oxxхymiron и Гнойным https://tinyurl.com/y8hjozzj
} 
испанского языка как иностранного исследователь предлагает работу с текстами, в которых речь идет о повседневной жизни героев, межи транскультурных конфликтах, где встречаются пограничные ситуации, описывается жизнь национальных и сексуальных меньшинств. Автор подчеркивает особое значение включения в программу обучения текстов писателей-мигрантов или жителей бывших (британских/испанских) колоний, в которых героями описываются поиски идентичности, проблематизируются культурно-этнические вопросы. Для обучаемых такой материал интересен именно опытом переживания этого процесса и формированием нового вида культурных практик.

Грит Альтер сформулировала критерии транскультурного обучения и разработала модели его преподавания для англистов на основе литературных текстов современных авторов-мигрантов, имеющих опыт проживания в мультикультурных обществах (Alter 2016). Исследовательница также подчеркивает важность выбора текстов и создания определенного пространства на занятиях, в котором для обучаемых возможно конструирование собственной идентичности при работе с т.н. гибридными текстами, отличающимися авторскими многоголосием и полифонией. По мнению Грит Альтер, сплетение культур/размытость их границ должны отражаться и на выборе методов работы и формулировке заданий обучения (Alter 2016, 52).

Учитывая опыт коллег и опираясь на собственные публикации в этой области, автор предлагает системный подход обучения студентоврусистов на базе мультимедийных материалов в меж- и транскультурном аспекте с ориентацией на требования современных стандартов западноевропейского образования.

Anastasia Drackert und Katrin Bente Karl (Hg.), Didaktik der slawischen Sprachen

Beiträge zum 2. Arbeitskreis in Innsbruck (19.02.-20.02.2018)

(C) 2019 innsbruck university press, ISBN 978-3-903187-80-1, DOI 10.15203/3187-80-1 


\section{2. Модель преподавания литературы в меж- и транскуль- турной перспективе}

Модель преподавания РКИ на мультимедийной основе в меж- и транскультурном аспекте была неоднократно описана нами в различных русско- и немецкоязычных публикациях (Caspers 2017; Caspers \& Scharlaj 2018; Брагина \& Касперс 2018; Caspers 2018). На данный момент этот метод, уже успешно прошедший фазу апробации в разных университетах (Москва, Тайбэй, Зальцбург и Алматы) находится в стадии доработки: дополняется теоретическая база для данной методики, а также ведется работа по составлению корпуса материалов, которые будут применяться при использовании данной модели, в том числе и в области автономного обучения.

Основными инновационными составляющими данной модели являются прежде всего формат работы (мультимедийный подход), выбор теоретической базы для структурированного анализа материалов (теория транскультурности Вольфганга Вельша (Welsch 2010)), лингвокультурный классификатор (Брагина \& Касперс 2017), модели транскультурной дидактики Райманна (Reimann 2015), а также корпус материалов авторов, имеющих опыт в области меж- и транскультурной коммуникации (в области литературы - Линор Горалик, Охххуmiron, Слава Сэ). При этом выбор жанра и авторов обусловлен несколькими обстоятельствами. Прежде всего - это наличие у авторов опыта создания меж- и транскультурных текстов и связанный с этим особый взгляд на повседневность, интертекстуальность (регулярные отсылки к классической или современной массовой литературе), небольшой объем текстов, отражение в них культуры повседневности, знакомый для обучаемых формат, возможность «живого» общения с авторами в интернете и социальных сетях (чтение комментариев и постов, комментирование в

Anastasia Drackert und Katrin Bente Karl (Hg.), Didaktik der slawischen Sprachen

Beiträge zum 2. Arbeitskreis in Innsbruck (19.02.-20.02.2018)

(C) 2019 innsbruck university press, ISBN 978-3-903187-80-1, DOI 10.15203/3187-80-1 
Instagram, Facebook и т.д.), и, наконец, актуальность обсуждаемых тем.

\section{3. Корпус текстов: Линор Горалик, Слава Сэ и Oxxxymiron}

Мультимедийные тексты авторов, выбранные для данной статьи, предлагают разные нарративные (жанровые) модели, художественные приемы и формы выстраивания сюжета, а также содержат многочисленные отсылки к мировой культуре и особенно литературе, что дает возможность работы с т.н. вертикальным контекстом (Ахманова \& Гюббенет 1977). По тематике тексты вышеперечисленных авторов соответствуют запросам возрастной категории обучаемых - так, например, целевая группа творчества Oxxхуmirona в России - это студенты и выпускники прежде всего гуманитарных направлений (Рондарев 2017). Но главное, что объединяет этих авторов, - это то, что их произведения можно причислить к т.н. «транскультурной» литературе. Линор Горалик, Охххуmiron и Слава Сэ - авторы, идентичность которых складывалась в условиях креолизации культур, и которые используют русский язык как lingua franca и имеют богатый личный опыт в области меж- и транскультурной коммуникации. Слава Сэ - русскоязычный автор, живущий за границей, описывает окружающую его действительность через призму русского иностранца и делает акцент на факты и события, необычные для носителя российской культуры (примеряя на себя т.н. роль „человека удивляющегося““(Брагина 2013: 254)). Его тексты интересны именно опытом смешивания традиций и формированием новых культурных практик. Линор Горалик, которая родилась в Украине, выросла в Израиле и уже во взрослом возрасте переехала в Россию, рассматривает окружающую ее российскую повседневность тоже с точки зрения иностранки. Творчество же

Anastasia Drackert und Katrin Bente Karl (Hg.), Didaktik der slawischen Sprachen

Beiträge zum 2. Arbeitskreis in Innsbruck (19.02.-20.02.2018)

(C) 2019 innsbruck university press, ISBN 978-3-903187-80-1, DOI 10.15203/3187-80-1 
Oxxxymirona, выросшего в Германии, получившего образование в Оксфорде и работающего на данный момент в России, являет собой пример par excellence создания транскультурного пространства, пересекающего границы нескольких культур.

Линор Горалик, проживающая с начала 2000-х в Москве, приобрела известность благодаря публикациям в интернете. Российско-израильская писательница является редактором интернет-портала Букник, пишет стихи и прозу, проводит лекции по теории современной повседневной культуры и организовывает выставки на различных московских культурных площадках. Горалик пишет на русском и иврите, имеет большой опыт в сфере меж- и транскультурной коммуникации благодаря проживанию в странах с высоким уровнем миграции. Писательница, творчество которой сформировалось на границе нескольких культур, литературных жанров и разного рода творческой деятельности (экономист, поэтесса, журналист, блогер, создательница комиксов и стикеров-эмоджи), публикует, кроме того, статьи в онлайн-журнале «Теория моды», которые можно эффективно задействовать при обучении студентов-русистов. Так, например, статья Стыдно как во сне (Горалик 2012) уже успешно применялась автором на занятиях в качестве материала по написанию студентамирусистами рефератов и в качестве основы для создания собственных текстов.

Для работы по модели преподавания литературы в меж- и транскультурном аспекте на уровне В2+/C1 (особенно для носителей русского языка как семейного) подходят такие тексты автора как Недетская еда. Без сладкого (2007) и роман Нет (2017). Первая книга представляет собой особый интерес для межкультурного обучения уже тем, что этот сборник короткой прозы, состоящий из наблюдений за повседневностью в России и других странах, сфокусирован на теме еды. Еда рассматривается автором как способ национальной самоидентификации, конструирования образа своих и чужих, как

Anastasia Drackert und Katrin Bente Karl (Hg.), Didaktik der slawischen Sprachen

Beiträge zum 2. Arbeitskreis in Innsbruck (19.02.-20.02.2018)

(C) 2019 innsbruck university press, ISBN 978-3-903187-80-1, DOI 10.15203/3187-80-1 
способ познания чужой культуры, путь к установлению коммуникативных связей. Кроме того, Горалик активно общается со своими читателями и подписчиками в социальных сетях (Facebook, Twitter и Instagram), комментирует высказывания, отвечает на вопросы, что дает возможность наблюдать за «живым общением» в русскоязычном интернете и на практике способствует укреплению коммуникативной компетенции.

Oxxxymiron - псевдоним Мирона Федорова - на данный момент самого известного русскоязычного рэп-исполнителя (Нилов 2017). Он собирает на своих выступлениях - баттлах - огромные аудитории и имеет свыше миллиона подписчиков на популярных платформах Instagram и Twitter. В 2015 году его альбом Горгород, своеобразный рэп-роман, состоящий из 11 песен, в которых даже искушенного читателя удивляет плотная интертекстуальная насыщенность отсылками к классике, включающая творчество таких авторов как Осипа Мандельштама, Владимира Маяковского, Демьяна Бедного, Джона Толкиена и братьев Стругацких, стал одной из самых продаваемых пластинок года (Забалуев 2015), а в 2018 вошел в лонглист литературной премии имени Александра Пятигорского ${ }^{3}$.

Выстраивая композиции своих альбомов как многоуровневые аудиоспектакли, зачастую выходящие за пределы однозначных жанровых определений, Охxхуmiron создает новые гибридные формы, что транслируется и на уровне музыки. Выпускник престижного университета (в области истории английской литературы) и любитель Серебряного века возродил популярность лирики в слегка измененном формате рэп-баттлов, собирая как раньше Евтушенко или Рождественский полные стадионы поклонников. За последнее время Oxxхymiron стал знаковой фигурой российской рэповой

\footnotetext{
${ }^{3}$ Оксимирона номинировали на литературную премию:

https://www.youtube.com/watch?v=Y4FUlTv2rrc

Anastasia Drackert und Katrin Bente Karl (Hg.), Didaktik der slawischen Sprachen

Beiträge zum 2. Arbeitskreis in Innsbruck (19.02.-20.02.2018)

(C) 2019 innsbruck university press, ISBN 978-3-903187-80-1, DOI 10.15203/3187-80-1
} 
субкультуры и уже в 2015 году был выпущен сериал Лондонград, созданный на основе некоторых эпизодов из его биографии (Никитин 2015).

Творчество Охххуmirona являет собой пример культуры поэтических споров и особенно интересна в этом плане диалогичность формы его баттлов. Использование текстов этого автора дает возможность наблюдения за способами урегулирования или же разворачивания/нагнетания конфликта (баттл - от слова битва, т.е. сражение двух противников) на примерах живого общения в определенных субкультурах. Кроме того, постоянное присутствие Охххуmirona в СМИ, его видеоклипы и другие выступления представляют собой продуктивный аудио- и видеоматериал для культурологического анализа на уровне B2+/C1. Наличие научно-популярных статей о рэпере способствует задействованию его текстов в работе со студентами-славистами, особенно с т.н. «херитажниками» и билингвами (Нилов 2017, Никитин 2015, Рондарев 2017).

Слава Сэ - псевдоним латвийского автора Вячеслава Солдатенко, также пишущего на русском языке. Рассказы блогера из Латвии являются оптимальным литературным материалом, поскольку он, проживая в Риге в мультикультурном обществе с непосредственным взаимодействием разных культур (русские, латыши, иностранцы из стран ЕС), пишет о происходящем на русском языке. Его тексты предлагают занимательные бытовые ситуации, знакомящие иностранных студентов с артефактами повседневной культуры в процессе ее активного взаимодействия с другими культурами, демонстрируя разные ситуации транскультурного общения (уровень А2+ или Б1). Рассказы Славы Сэ характеризуются, кроме того, наличием интертекстуальности (отсылки к классической литературе, музыке, современным отечественным и зарубежным фильмам и т.д.), что дает возможность при работе с короткими текстами применять различные культурологические теории и системно анализировать значимые для

Anastasia Drackert und Katrin Bente Karl (Hg.), Didaktik der slawischen Sprachen

Beiträge zum 2. Arbeitskreis in Innsbruck (19.02.-20.02.2018)

(C) 2019 innsbruck university press, ISBN 978-3-903187-80-1, DOI 10.15203/3187-80-1 
МиТКК явления на практике. Новые тексты блогера появляются несколько раз в месяц на его странице в ЖЖ и на Facebook, представляя собой образец ультрасовременной культуры.

Кроме того, рассказы Славы Сэ обычно имеют объем не больше одной страницы, лексика достаточно доступна для понимания, что является немаловажным фактором при отборе текстов для работы с иностранными студентами. Поскольку дочь автора, являющаяся героиней многих его рассказов и постов на ФБ, на данный момент проходит обучение в Германии, то и тематика материалов «обучения за рубежом» делает его творчество еще более эффективным для работы на университетских занятиях. В конце концов, пример непрофессионального писателя, имеющего многотысячную читательскую аудиторию, может мотивировать студентов к написанию собственных текстов в большей степени, чем опыт «профессиональных» авторов (Касперс 2017а).

\section{4. Методика работы с мультимедийными текстами}

Начинать работу с мультимедийными текстами рекомендуется с т.н. вводной части, дающей общее представление о теоретической базе меж- и транскультурной коммуникации: основные направления и перспективы, параметры сравнения культур, а также теория транскультурности Вольфганга Вэльша (Welsch 2010) ${ }^{4}$. После этого следует перейти к практической части, различая при этом следующие уровни меж- /и транскультурной коммуникативной компетенции: (1) уровень знаний (фоновые знания о стране изучаемого языка таких,

4 Подробнее: Тематический классификатор лингвокультурных моделей и возможности его применения в преподавании славянских языков и культур, in: Wiener Slawistischer Almanach 81 (2018), 33-55.

Anastasia Drackert und Katrin Bente Karl (Hg.), Didaktik der slawischen Sprachen

Beiträge zum 2. Arbeitskreis in Innsbruck (19.02.-20.02.2018)

(C) 2019 innsbruck university press, ISBN 978-3-903187-80-1, DOI 10.15203/3187-80-1 
как политика, социология, религия, география и так далее); (2) уровень языка и культуры, включающий в себя специфику и культурологические особенности словарного запаса, определенные лингвокультурные концепты и т.д.; (3) уровень социокультурных знаний и умений, имплицирующий знание и умение узнавать и адекватно реагировать на ритуалы и традиции изучаемой культуры; (4) уровень культурного трансфера (Caspari \& Schinschke 2009). При практических заданиях рекомендуется использовать модели анализа мультимедийных материалов в аспекте МиТКК, подробно описанные автором статьи (Касперс 2017, Брагина \& Касперс 2018). В заключение стоит сконцентрироваться на т.н. креативной части написании собственных текстов на основе прочитанного и проанализированного материала.

Поскольку меж- и транскультурная компетенции - сложные, многоуровневые явления, для формирования которых еще не выработано четких методологических установок, то для работы в этой сфере необходимы соответственно и многоуровневые модели преподавания, которые, в свою очередь, могли бы служить основой как для диагностики, так и для тестирования знаний в этой области. В связи с этим предлагается выделять несколько уровней анализа мультимедийных материалов в аспекте МиТКК:

- артефакты: высокая (литература, музыка, театр, изобразительное искусство) и повседневная культура (мода, кулинария, домашний и городской интерьер, спорт и культура тела, сфера свободного времени и развлечений и т.д.);

- национальные особенности культуры: поведенческие стандарты (традиции, ритуалы и т.д.);

- язык и культура: лингвокультурологические концепты (категория вежливости, отношение к правде, закону, деньгам, красоте, здоровью, времени и т.д.); 
- система ценностей, параметры сравнения культур (маскулинность/фемининность, коллективизм/индивидуализм, избегание неопределенности, планирование и т.д.);

- стереотипы: русские о других культурах и о себе, другие культуры о русских;

- культурный трансфер/гибридизация культур (вопросы заимствований из одной культуры в другую, их переплетения/смешивания).

Непосредственно работу стоит начинать с описания и выстраивания гипотез о содержании текстов по названию или имеющимся материалам (иллюстрациям, фотографиям, видеоклипам и т.д.) с учетом вопросов культурологии и МиТКК. Такой тип заданий направлен на подготовку дискуссии: они задействуют аффективный уровень и апеллируют к уже имеющемуся опыту обучаемых. Кроме того, они способствуют формированию навыка выстраивания гипотез и аргументации. На этом же этапе работы рекомендуется проводить работу со специфической лексикой, которая облегчит понимание материала. На данном этапе работы можно прослушать тексты в аудио-формате, останавливая прослушивание/просмотр/чтение с последующим заданием рассказать, что будет дальше, аргументируя ответ.

Во время прослушивания/просмотра/чтения можно предложить студентам войти в роль «человека удивляющегося» и фиксировать на их взгляд - культурные и отклонения в поведении персонажей или развитию сюжетной линии. Крайне важно на этом этапе отмечать моменты незнания/непонимания и недопонимания, чтобы потом обсудить их с преподавателем. Кроме того, необходимо, чтобы при прослушивании/просмотре/чтении материалов студенты искали ответы на поставленные вопросы по содержанию, что позволит сфокусировать их внимание на важных для анализа моментах.

Anastasia Drackert und Katrin Bente Karl (Hg.), Didaktik der slawischen Sprachen

Beiträge zum 2. Arbeitskreis in Innsbruck (19.02.-20.02.2018)

(C) 2019 innsbruck university press, ISBN 978-3-903187-80-1, DOI 10.15203/3187-80-1 
После прослушивания/просмотра/прочтения предлагается обсудить прежде всего проблемы непонимания и недопонимания. При этом акцент здесь можно сделать на сравнение материала с собственной лингвокультурой (когнитивный/аффективный уровень). Затем рекомендуется проводить обсуждение в группах: сначала артефактов высокой и повседневной культуры, потом лингвокультурных концептов, после чего заняться разбором стереотипов и параметров сравнения культур, а после этого перейти к обсуждению культурных сходств - т.о. анализируя транскультурные явления (Подробнее: Брагина/Касперс 2018). Данные задания направлены, прежде всего, на развитие способности к самонаблюдению и саморефлексии, являющейся важной предпосылкой для успешного меж- и транскультурного обучения (когнитивный уровень). Помимо этого, здесь можно тренировать навык рефлексии по отношению к родной культуре и ее сравнение с другой/другими, а также поиск сходных культурных элементов. Для этого подходят материалы с большим количеством перспектив/голосов и трактовок, которые в свою очередь отражают различные культурные влияния. Таким образом, обучаемые, задумываясь над прочитанным, используют материал для самопозиционирования, создания моделей самоидентификации, испытывают сомнения в собственной правоте по отношению к некоторым темам.

После обсуждения и культурологического анализа (особенно интертекстуальных отсылок) рекомендуется дать студентам задание написать собственные тексты с учетом отработанного материала и знаний /умений и навыков, приобретенных на занятиях по литературоведению и культурологии (конативный уровень). Готовые тексты можно разместить на внутриуниверситетских платформах (Moodle) и дать задание в группе: написать рецензию на работы коллег или же прокомментировать их. Кроме того, можно заняться написанием общего текста в группах (т.н. коллаборативное письмо).

Anastasia Drackert und Katrin Bente Karl (Hg.), Didaktik der slawischen Sprachen

Beiträge zum 2. Arbeitskreis in Innsbruck (19.02.-20.02.2018)

C 2019 innsbruck university press, ISBN 978-3-903187-80-1, DOI 10.15203/3187-80-1 


\section{5. Пример работы по модели (Oxxxymiron)}

В качестве примера для работы по выше предложенной модели были выбраны два трека с концептуального альбома рэп-исполнителя Горгород: Переплетено ${ }^{5}$ и Город под подошвой. ${ }^{6}$ При выборе материала автор статьи руководствовалась прежде всего прагматическими соображениями (небольшой объем текстов), а также возможностью обратить внимание обучаемых на такой «немодный» на сегодняшний день жанр, как лирика. Выбор трека «Переплетено» был обусловлен еще и тем фактом, что он является наилучшей демонстрацией понятия транскультурности Вэльша, для которого значимую роль играет именно смешивание и переплетение культур. Такие выражения, как все переплетено, полотно, ткань, сеть и т.д. являются главными метафорами для объяснения теории транскультурности Вельша (ср. текст: Ваша картина мира сетка/Полотно, текстильная салфетка/Будто работала ткачиха или швейка/Но все переплетено - само собою, набекрень, наискосок ${ }^{7}$ ). Кроме того, уже творческий псевдоним исполнителя Oxxxymiron - дает материал для обсуждения вопросов МиТКК: смешение литературного понятия оксюморон и имени рэпера Мирон, написанное латинскими буквами, делает введение в тему теории транскультурности оптимальным.

\footnotetext{
${ }^{5}$ На платформе YouTube предлагается для просмотра оригинальный видеоклип к песне Переплетено https://www.youtube.com/watch?v=WazC2PUy5v4, a также видео, сделанное фан-клубом Оххутіrona, с видеорядом больше подходящим для анализа транскультурной тематики данной композиции https://www.youtube.com/watch?v=DEhJsRFFFHo

${ }^{6}$ Предлагаемый материал был разработан в совместном проекте/сотрудничестве с МГУ и семинаром Марии Араповой в рамках работы по созданию корпуса мультимедийных текстов для анализа в аспекте МиТКК.

${ }^{7}$ Переплетено https://www.youtube.com/watch?v=DEhJsRFFFHo
}

Anastasia Drackert und Katrin Bente Karl (Hg.), Didaktik der slawischen Sprachen

Beiträge zum 2. Arbeitskreis in Innsbruck (19.02.-20.02.2018)

(C) 2019 innsbruck university press, ISBN 978-3-903187-80-1, DOI 10.15203/3187-80-1 
Кроме того, тексты рэпера тематизируют такой типичный для этой субкультуры вопрос, как насилие, являющийся на данный момент одной из основных составляющих современной российской культуры. Известный философ и культуролог Михаил Ямпольский в своей книге Парк культуры: Культура и насилие в Москве сегодня указывает на то, что основным вектором современной российской культуры является ее соотношение с разными видами насилия: культурного, символического, психологического, государственного и т.д. (Ямпольский 2018). Эти тенденции взаимного влияния можно проследить и в творчестве Охххуmirona: парадоксальное сочетание субкультуры российского рэпа, относящейся скорее к низовой культуре (наличие тем разного рода насилия, употребление наркотиков, воспевание брутальности и употребление обсценной лексики) и классики - культуры Серебряного века с ее культом Прекрасной дамы, избранности роли поэта в обществе, элитарностью особой ролью лирики в литературной сфере и т.д.

Декларированный интеллектуализм, а также тематическая близость текстов Охxхуmirona студентам-филологам тоже является одной из причин, по которым автор рекомендует работу именно с этим исполнителем. Личный опыт в области меж- и транскультурного общения с акцентом на креолизацию/сплетение культур, продуктивно сказывается на работе с композициями музыканта в группах со студентами-херитажниками и предоставляет благоприятное пространство для конструирования транскультурной идентичности обучаемых.

Поскольку для Охххуmirona особенно характерна транскультурная составляющая творчества (пересечение границ, восприятие других культур), то его биография является важным фактором анализа, и начинать работу с текстами рекомендуется с поиска информации о месте рождения и проживания, роде образования, владении языками,

Anastasia Drackert und Katrin Bente Karl (Hg.), Didaktik der slawischen Sprachen

Beiträge zum 2. Arbeitskreis in Innsbruck (19.02.-20.02.2018)

(C) 2019 innsbruck university press, ISBN 978-3-903187-80-1, DOI 10.15203/3187-80-1 
информации о роде деятельности и присутствии в медийном пространстве этого исполнителя (Facebook, Instagram, Twitter). Креолизация культур в его творчестве соответствует гибридности текстов исполнителя: рэп - жанр, соединяющий индивидуальное, национальное и универсальное.

Кроме того, в текстах Охххутіrona переплетаются сферы высокой культуры (античность, современный театр, лирика Серебряного века) с вопросами повседневной культуры (бытовые проблемы выпускника филфака, зарабатывание средств на существование и т.д.).

Работать с композициями Охххуmirona рекомендуется на трех уровнях:

- уровне текста (разбор лексики, специфика лингвокультурологических концептов, культурных артефактов, стереотипов и национальных особенностей)

- уровне метатекста (условия возникновения альбомов и их продвижение в социальных сетях, рецепция)

- уровне интертекста (анализ наличия интертекстуальных связей с русской и мировой литературой, особенно ярко представленных в творчестве этого рэп-исполнителя).

Начать работу с саундтреками рекомендуется с обсуждения заставки к альбому, на которой изображена Вавилонская башня, несомненно являющаяся символом смешения языков и культур. Студентам можно дать задание обсудить в группах возможную тематику альбома с такой заставкой. Перед просмотром необходимо обсудить название треков Переплетено и Город под подошвой в аспекте теории транскультурности (переплетения/гибридности культур) Вольфганга Вэльша. На уровне работы с лексикой в рамках предтекстовых заданий возможны следующие задания:

Anastasia Drackert und Katrin Bente Karl (Hg.), Didaktik der slawischen Sprachen

Beiträge zum 2. Arbeitskreis in Innsbruck (19.02.-20.02.2018)

(C) 2019 innsbruck university press, ISBN 978-3-903187-80-1, DOI 10.15203/3187-80-1 
- Объясните значение таких слов, как мерч, минивэн, портативные постели, корпоратив.

- Что можно плести? Обратитесь к словарям за дополнительной информацией.

- Какие инструменты используют для плетения?

- Продолжите ряд: плести, переплетать, связывать, ткать...

- Разделите слова на 2 группы: клубок, ткань, текстиль, сетка, моток, салфетка, комок нитей, сеть. Объясните принцип своего разделения.

В качестве притекстовых рекомендуются следующие задания:

- Приведите примеры сетей (телефонная, информационная, телекоммуникационная, нейронная, сосудистая, дорожная).

- Прочитайте текст рэп-трека, какие слова, с вашей точки зрения, являются ключевыми для данного текста?

- Как в тексте трека вербализуется концепт СВЯЗЬ?

- Перечислите, что переплетено и связано в Горгороде.

На следующем этапе работы предлагается проводить обсуждение в группах: сначала артефактов высокой и повседневной культуры, присутствующих в тексте трека и видеоклипе; потом лингвокультурных концептов, после чего заняться разбором стереотипов и параметров сравнения культур; после этого перейти к обсуждению культурных сходств - т.о. анализируя транскультурные явления. При обсуждении особое внимание стоит уделить субкультуре рэпа вопросам моды (спортивный стиль: худи, тренировочные костюмы, кепки), культуре тела (традиция татуировок, пирсинга, ношение украшений и т.д.), городскому и личному пространству (броник, концертные залы), концептам семьи и здоровья (больше чем семья, домашний Парацельс), параметру коллективизма и маскулинности субкультуры рэпа, а также анализу рэпа как транскультурного феномена на музыкальной сцене. Кроме того, можно обсудить 
упоминание в тексте саундтрека поэта Сергея Есенина, символизирующего образ народного гения и хулигана, злоупотребляющего как алкоголем, так и матом. Для студентов-литературоведов можно дать задание объяснить понятие хронотопа по Бахтину на примере данной композиции (сочетание принципа дороги и времени: Дон, Волга, Краснодар, Татарстан, Москвабад, МКАД, Мадагаскар, мост в Асгард).

В качестве после-текстовых заданий по треку «Переплетено» рекомендуются следующие:

- выпишите из текста все интертекстуальные отсылки.

- используя справочно-информационные источники, определите их значение, источник, ассоциативный ряд и смысл использования в тексте рэп-трека. 


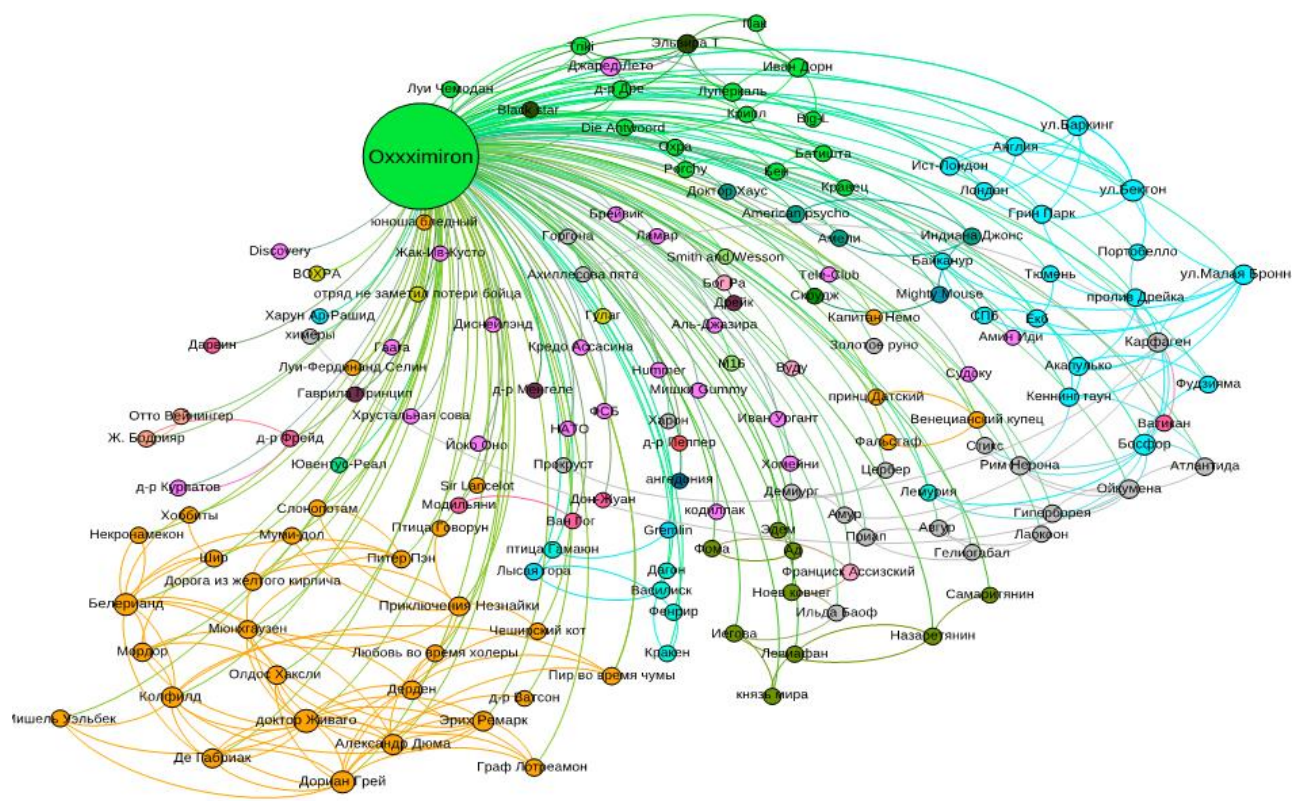

График Gephi 0.9.2

Альбом «Долгая дорога домой»: оранжевый - мировая литература; розовый современная культура и политика; серый - античность, ярко-голубой топонимы, светло-зеленый - субкультура рэперов, болотный - библия, малиновый - европейская культура, бледно-розовый - мировые религии, бирюзовый - мифология, сине-зеленый - кинематограф, желтый - советская культура, лиловый - Европейская история, темно-зеленый - музыка, персиковый - философия + фольклор, оружие, спорт, мультипликация, семитская культура, психиатрия, история Ближнего Востока.

На графике, составленном нами при помощи программы Gephi 0.9.2, представлены интертекстуальные отсылки альбома Oxxхуmirona, демонстрирующие огромное количество культурологических аллюзий в творчестве рэпера. Использовать их можно при составлении

Anastasia Drackert und Katrin Bente Karl (Hg.), Didaktik der slawischen Sprachen Beiträge zum 2. Arbeitskreis in Innsbruck (19.02.-20.02.2018)

(C) 2019 innsbruck university press, ISBN 978-3-903187-80-1, DOI 10.15203/3187-80-1 
заданий различного уровня языковой сложности. Так, например, можно предложить следующие задания по исследованию вертикального контекста для студентов-херитажников:

- Сравните вертикальный контекст творчества рэпера Oxxxymirona и Eminem, Lil Реep или одного из немецких рэперов на ваш выбор (баттл-лига/Rap am Mittwoch)

- Сравните вертикальный контекст (использование источников аллюзивных фигур) рэп-треков Охxхуmirona и одного из поэтов Серебряного века

После обсуждения вышеперечисленных уровней по модели МиТКК следует дать креативные задания по написанию собственных текстов, а при наличии технических возможностей - по созданию визуального ряда к композиции «Переплетено». Кроме этого, рекомендуется дать задание по написанию отзыва, статьи, эссе или заметки об авторе в перспективе проблем МиТКК, учитывая историю возникновения альбома рэпера «Горгород» и его рецепции. Считывание «интеллектуальной начинки» в треках Охххуmirona делает его творчество популярным, особенно среди студентов столичных российских вузов. Именно этот аспект является важным для использования уже имеющихся знаний студентами-филологами в области классической русской литературы как в работе с треками рэпера, так и при написании собственных текстов.

\section{6. Заключение}

В заключительных кадрах фильма Такое настроение, адажио Баха и небольшой фрагмент из жизни девушки Лень, процитированного во введении к статье, московские гастарбайтеры, собирающие мусор на

Anastasia Drackert und Katrin Bente Karl (Hg.), Didaktik der slawischen Sprachen

Beiträge zum 2. Arbeitskreis in Innsbruck (19.02.-20.02.2018)

(C) 2019 innsbruck university press, ISBN 978-3-903187-80-1, DOI 10.15203/3187-80-1 
улицах, по прошествии нескольких недель все-таки грузят пианино, на котором когда-то играли Баха, в мусоровоз. Пианино - как метафора высокого искусства - в современном городе оказывается никому не нужным. По аналогии можно сформулировать тезис, что эффективное использование русской классики в немецких вузах возможно только в ее «прикладном» аспекте - таком как распознавание интертекстуальных отсылок (т.н. вертикальный контекст), тренировке навыков МиТКК, а также улучшению литературноэстетических компетенций. При этом на занятиях по РКИ необходимо задействование литературы, которая не только учитывает интересы обучаемых на разных уровнях, а также создает особое транскультурное пространство, в котором возможно создание текстов в рамках размышления над собственной национальной идентичностью. Представленная в статье модель работы с мультимедийными текстами и выбор авторов предоставляют возможность такого использования материалов.

Подводя итоги, необходимо отметить, что работать с классическими произведениями практически невозможно в рамках занятий по РКИ, предусмотренных по программе обучения магистров или бакалавров, но возможно так заинтересовать студентов тематикой и разработать практические материалы для автономного обучения, что они смогут, самостоятельно работая по данной модели, расширять и углублять свои знания в области современной культуры и литературы, анализировать культурные события в России в аспекте МиТКК, а также практиковаться в создании собственных текстов, экспериментируя с формой и жанрами. 


\section{Литература}

Alter, G. (2016). Transkulturelle Kompetenzen durch transkulturelle Literatur - Implikationen für den Fremdsprachenunterricht. In M. Rückl (Hrsg.), Sprachen und Kulturen: vermitteln und vernetzen: Beiträge zu Mehrsprachigkeit und Inter-/Transkulturalität im Unterricht, in Lehrwerken und in der Lehrer/innen/bildung (50-61). Münster: Waxmann.

Bergmann, A. (2016). Kompetenzorientierung und Schüleraktivierung im Russischunterricht. Frankfurt am Main; Peter Lang.

Bourdieu, P. (1983). Ökonomisches Kapital, kulturelles Kapital, soziales Kapital. In R. Kreckel (Hrsg.), Soziale Ungleichheiten (Soziale Welt, Sonderheft 2) (183-198). Göttingen: Otto Schwartz \& Co.

Caspers, O. (2017). Bilingual education in German speaking countries: a transcultural model of tuition. RUDN Journal of Language Education and Translingual Practices, 14 (2), 276-286.

Caspers, O. \& Scharlaj, M. (2017). Party Like A Russian! Zur kulturdidaktischen Analyse von Musikvideos im universitären Unterricht. In A. Bergmann, O. Caspers \& W. Stadler (Hrsg.), 1. Arbeitskreis ,,Didaktik der Slawischen Sprachen "in Berlin (12.-14.9.2016), (113135). Innsbruck: innsbruck university press.

Dawidowski, C., Hoffmann, A. \& Walter, B. (Hrsg.) (2015). Interkulturalität und Transkulturalität in Drama, Theater und Film. Frankfurt am Main: Peter Lang.

Decke-Cornill, H. \& Küster, L. (2015). Fremdsprachendidaktik: Eine Einführung. Tübingen: Narr Francke Attempto.

Fäcke, C. (2006). Transkulturalität und fremdsprachliche Literatur: Eine empirische Studie zu mentalen Prozessen von primär mono oder bikulturell sozialisierten Jugendlichen. Frankfurt am Main: Peter Lang.

Lampl, E., Cavic-Podgornik, N. \& Wurm, B. (2008). Russisch für Anfänger. Wien: Verlag Berger.

Anastasia Drackert und Katrin Bente Karl (Hg.), Didaktik der slawischen Sprachen

Beiträge zum 2. Arbeitskreis in Innsbruck (19.02.-20.02.2018)

(C) 2019 innsbruck university press, ISBN 978-3-903187-80-1, DOI 10.15203/3187-80-1 
Reimann, D. (2014). Transkulturelle kommunikative Kompetenz in den romanischen Sprachen: Theorie und Praxis eines neokommunikativen und kulturell bildenden Französisch-, Spanisch-, Italienischund Portugiesischunterrichts. Stuttgart: Ibidem.

Welsch, W. (2010). Was ist eigentlich Transkulturalität? In L. Darowska, T. Lüttenberg \& C. Machold (Hrsg.), Hochschule als transkultureller Raum? Kultur, Bildung und Differenz in der Universität (39-66). Bielefeld: transcript.

Ахманова, О. \& Гюббенет, И. (1977). „Вертикальный контекст“ как филологическая проблема. Вопросы языкознания № 3, 47-54.

Брагина, Н. (2013). Лексикон межкультурной коммуникации: межкультурный диалог и «человек удивляющийся». Гаспарян, Г.Р. (гл. ред.), Русский язык в формате 3D: лингвистика, образование, культура (254-261) Ереван: Лингва.

Брагина, Н. \& Касперс, О. (2018). Тематический классификатор лингвокультурных моделей и возможности его применения в преподавании русского языка и культуры, Wiener Slawistischer Almanach 81, 33-55.

Горалик, Л. (2012). Стылно, как во сне: Адекватность костюма: субъективная тревога и поиск объективных факторов. Verfügbar unter: https://tinyurl.com/unc2rxo [12.11.2018].

Забалуев, Я. (2015). Как я стал писателем. Вышел второй альбом Оксимирона. Verfügbar unter: https://tinyurl.com/sa4stqp [12.11.2018].

Какие книги упомянули в баттле Охххутіron и Слава КПСС (Гнойньій) (2017). Verfügbar unter: https://tinyurl.com/wfty9vy [12.11.2018].

Касперс, О. (2017). Формирование меж- и транскультурных навыков в преподавании РКИ на основе современной российской интернет-литературы (на примере работы с текстами Славы Cэ). Międzynarodowa Konferencja Naukowa: Człowiek Świadomość Komunikacja Internet, UNIWERSYTET WARSZAWSKI, Warszawa, Band 2, 28-39.

Anastasia Drackert und Katrin Bente Karl (Hg.), Didaktik der slawischen Sprachen

Beiträge zum 2. Arbeitskreis in Innsbruck (19.02.-20.02.2018)

(C) 2019 innsbruck university press, ISBN 978-3-903187-80-1, DOI 10.15203/3187-80-1 
Касперс, О. (2017). Билингвальное образование в немецкоязычных странах: модель транскультурного обучения, Вестник Российского университета дружбы народов. Серия: Вопросы образования: языки и специальность. Т. 14. № 2., 276-287.

Миллер, Л. \& Политова, Л. (2009). Жили-были, Санкт-Петербург: Златоуст.

Меликян, А. (2014). Такое настроение, адажио Баха и небольшой фрагмент из жизни девушки Лены. Verfügbar unter: https://tinyurl.com/qohg5yt [12.11.2018].

Никитин, А. (2015). „По моим приключениям снимается сериал“: Oхххуmiron и Михаил Идов о ,Лондонграде“. Verfügbar unter: https://tinyurl.com/twed22q [12.11.2018].

Нилов, С. (2017). От Оксфорда до «рил ток»: Из чего состоит Оксимирон. Творчество главного рэпера страны от А до Я. Verfügbar unter: https://tinyurl.com/swqpwmh [12.11.2018].

Рондарев, А. (2017). «Наи великий поэт - Оксимирон». Verfügbar unter: https://tinyurl.com/t6k4vdf [12.11.2018].

Чернышов, С. (2010). Поехали! Русский язык для взросльхх. Санкт Петербург: Златоуст.

Эсмантова, Т. (2009). Русский язык. 5 элементов. Санкт-Петербург: Златоуст.

Ямпольский, М. (2018). Парк культуры: Культура и насилие в Москве сегодня. Москва. Новое издательство.

Anastasia Drackert und Katrin Bente Karl (Hg.), Didaktik der slawischen Sprachen

Beiträge zum 2. Arbeitskreis in Innsbruck (19.02.-20.02.2018)

(C) 2019 innsbruck university press, ISBN 978-3-903187-80-1, DOI 10.15203/3187-80-1 
